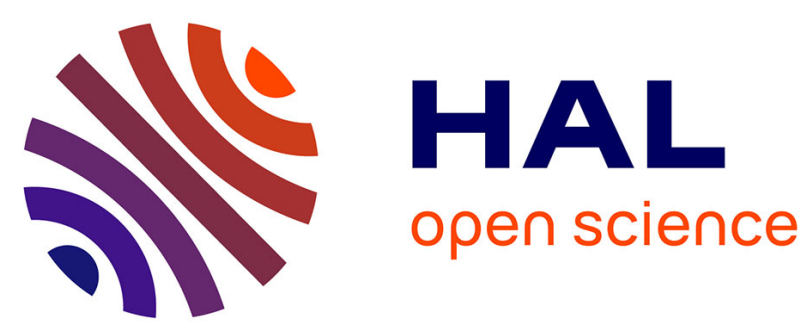

\title{
Leader of my Heart!
}

\author{
Alexander Frame, Gilles Brachotte
}

\section{To cite this version:}

Alexander Frame, Gilles Brachotte. Leader of my Heart!: Use of Twitter by Leaders' Partners during Election Campaigns. Alexandre-Collier, A. \& De Chantal, F. Leadership and Uncertainty Management in Politics, Palgrave, pp.111-126, 2015, 10.1057/9781137439246_8. hal-01429648

\section{HAL Id: hal-01429648 https://hal.science/hal-01429648}

Submitted on 9 Jan 2017

HAL is a multi-disciplinary open access archive for the deposit and dissemination of scientific research documents, whether they are published or not. The documents may come from teaching and research institutions in France or abroad, or from public or private research centers.
L'archive ouverte pluridisciplinaire HAL, est destinée au dépôt et à la diffusion de documents scientifiques de niveau recherche, publiés ou non, émanant des établissements d'enseignement et de recherche français ou étrangers, des laboratoires publics ou privés. 


\title{
8. Leader of my Heart! Use of Twitter by Leaders' Partners during Election Campaigns
}

\author{
Alex Frame and Gilles Brachotte
}

The first decade of the twenty-first century has witnessed the emergence of "new" media technologies which have contributed to reshaping the relationships between politicians, journalists and the general public in Western democracies and around the world (Fox \& Ramos, 2012; Lilleker \& Jackson, 2013). After diverse early attempts in several countries to harness these new tools during election periods, their use by Barack Obama's campaign team in the 2008 US presidential elections is often cited as one of the first examples in which they appeared to contribute positively to mobilising sympathisers and party activists around the campaign (Thimm, 2011). In the subsequent 2010 UK general election and the 2012 French and US presidential elections, explored in this chapter, all major parties exploited web-based tools, including Facebook and Twitter accounts, websites, blogs and dedicated online platforms used to coordinate local campaign actions. Alongside the official party tools, many individual candidates and virtually all major party / political leaders had their own dedicated social media accounts through which they could communicate. In social terms, this evolution seems to be linked to a broader trend towards the "personalisation" of politics and political communication, notably that of political leaders (Seiler, 2002). Social media may (naïvely) be seen by politicians and voters as a direct, im-media-te, "horse's mouth" channel through which politicians and party leaders can voice their ideas and opinions directly to voters. Moreover, such tools can also be associated with the "intimization" of politics (Stanyer, 2013: 14) $)^{1}$ notably in the light of social representations of the use of Facebook and Twitter among adolescents to publicly display what can often be considered intimate details. Politicians' tweets or posts on Facebook can thus be framed as part of a more global selfpresentation strategy (Goffman, 1959), sometimes including information from the private / personal / intimate sphere ${ }^{2}$ (Frame, 2012; Frame \& Brachotte, 2013).

In the case of party leaders, personalisation or intimization strategies can also be associated at times with a bid to appear "normal" - to borrow a term frequently used by François Hollande during the 2012 French presidential election. David Cameron has notably been said to adopt this strategy, in the light of his innumerable media appearances (Craig, 2014), and notably when he refers to his family or domestic situation (Alexandre-Collier, 2010: 122). In the video posted on his video blog "Webcameron", on Election Day in 2010, for example, he addresses his audience in his shirt 
sleeves, stood in a kitchen, exhorting them to go out and vote. ${ }^{3}$ Other campaign videos on Cameron's blog feature his wife Samantha, who, we have argued elsewhere (Brachotte \& Frame 2011), can be seen to contribute to strengthening this domestic image of the political leader who is also a father and a husband. Indeed, although the figure of "First Lady" has long been mediatised, Stanyer (2013: 11) notes that in both the US and the UK, leaders' wives are under increasing media scrutiny. The same is true of France, as noted by Constance Vergara (2012) in her interview-based review of the evolving role of First Lady in that country. Christiane Restier-Melleray (2002: 124) further highlights the importance of the role played by leaders' companions in this process of intimization, suggesting that they often serve to underscore the leaders' private virtues, while portraying them as "ordinary" (married) people.

The authors of this chapter consider that the popularity but also the perceived legitimacy of modern leaders in Western democracies is very often directly related to their own personal skills as communicators, but equally that their image, notably in the context of election campaigns, also depends on the way that their wives / partners ${ }^{4}$ contribute to portraying them. These presentations, notably through social media channels, which might portray a leader as particularly virtuous, for example, may be seen to contribute to his / her "cult of personality". This might seem compatible with a communication strategy to present a "charismatic leader" in Weber's sense of "charismatic authority" (Weber, 1947 [1922]). However, insisting on the leader's “ordinariness" or normality might actually have the opposite effect, since charismatic leaders are "set apart from ordinary men and treated as endowed with supernatural, superhuman, or at least specifically exceptional powers or qualities. These are such as are not accessible to the ordinary person, but are regarded as of divine origin or as exemplary, and on the basis of them the individual concerned is treated as a leader." (Weber, 1947 [1922]: 157).

This chapter examines the co-construction of the image of leader by the leaders' partners, by looking at the way in which one particular social media channel, Twitter, was used by partners during the 2010 general elections in the UK and the 2012 presidential elections in France and the US. It focuses on the way partners present themselves as spouses, parents, citizens, admirers or defenders of "their" candidates and the extent to which their tweets can be interpreted as efforts to bridge the symbolic, social and political gaps between leaders, followers and voters.

\section{Corpus and Methodology}

The global corpus, covering the three countries and elections, includes the (potential) Twitter activity of 13 leaders' partners over a given period of time leading up to each election. The British corpus covers the official election campaign of one month $\left(6^{\text {th }}\right.$ March $-6^{\text {th }}$ April 2010). It includes 
the wives of the three major party leaders: Sarah Brown, Samantha Cameron and Myriam González Durántez, wife of Liberal Democrat leader Nick Clegg. The French corpus also corresponds to the dates of the official 2-month presidential election campaign $\left(19^{\text {th }}\right.$ February $-20^{\text {th }}$ April 2012). It includes the partners of the five largest parties: Carla Bruni-Sarkozy, wife of the President in office; Valérie Trierweiler, partner of the Socialist candidate François Hollande; Louis Aliot, partner of Marine Le Pen, candidate for the Front National party; Elisabeth Bayrou, wife of centrist François Bayrou; plus the wife of Jean-Luc Mélenchon, representing the Front de Gauche. In the US, the corpus includes the Twitter accounts of Michelle Obama and the wives of the last four remaining Republican candidates seeking nomination by their party, in the nine months between the Iowa Caucuses ( $6^{\text {th }}$ February 2012) and Election Day (6 ${ }^{\text {th }}$ November 2012): Cally Gingrich, Carol Paul, Ann Romney and Karen Santorum. The tweets captured from the selected official accounts were subjected to content analysis, both to define recurrent words and themes and to identify the use of different operators in use on Twitter (http://; \#, @, RT), enabling us to characterise the "Twitter styles" (Dang-Anh, Einspänner, \& Thimm 2012) of different users.

\section{Political Contexts, Uses and Non-Uses of Twitter}

The partners studied showed very different strategies and practices on Twitter, ranging from nonuse (for over half of the sample) to intensive use for others. Figure 1 shows the number of tweets during the period and the number of followers at the end of the period for each partner.

\begin{tabular}{|c|c|c|c|}
\hline Partner & $\begin{array}{c}\mathrm{N}^{\circ} \text { of Tweets } \\
\text { Posted }\end{array}$ & Corpus Dates & 0 \\
\hline Aliot & 221 & \multirow{5}{*}{$\begin{array}{c}19^{\text {th }} \text { February }-20^{\text {th }} \\
\text { April } 2012\end{array}$} & 1,500 \\
\hline Bayrou & 0 & & 0 \\
\hline Bruni-Sarkozy & 0 & & 0 \\
\hline Mélenchon & 0 & & 0 \\
\hline Trierweiler & 42 & & 30,000 \\
\hline Brown & 359 & \multirow{3}{*}{$\begin{array}{c}6^{\text {th }} \text { March }-6^{\text {th }} \\
\text { April } 2010\end{array}$} & $1,100,000$ \\
\hline Cameron & 0 & & 0 \\
\hline González Durántez & 0 & & 0 \\
\hline Gingrich & $472(267)^{5}$ & \multirow{5}{*}{$\begin{array}{l}6^{\text {th }} \text { February }-6^{\text {th }} \\
\text { November } 2012\end{array}$} & $10,000(8,500)$ \\
\hline Obama & $82(576)^{6}$ & & $2,170,000$ \\
\hline Paul & 0 & & 0 \\
\hline Romney & 56 & & 170,000 \\
\hline Santorum & 0 & & 0 \\
\hline
\end{tabular}

Figure: Activity on Twitter during Election Campaigns, compiled by the authors

Use of Twitter by partners seems to be linked to a variety of factors, including their own 
professional activity, the electoral campaign itself, and the place of Twitter in the wider national media context. In May 2010, around 8\% of UK citizens had a Twitter account, a figure which had risen to around a third in 2012 (over 23M accounts). Around a third of US citizens also had an account in the first half of 2012 (around 107M accounts), whereas at the same period in France the proportion of users was still close to the 2010 British figure of $8 \%$ (just over $5 \mathrm{M}$ accounts) ${ }^{7}$. It can be surmised that there was less popular pressure for leaders' partners to have their own Twitter account in the UK in 2010 and in France in 2012 than in the US at this time.

Individual reasons for not opening an account do appear to vary, however. In France, declarations from François Bayrou and Jean-Luc Mélenchon and the almost total absence of their spouses and families from the media seem linked to a desire to protect their private lives. This is traditionally accepted in France, especially from leaders who have only very slim hopes of becoming President. Indeed, Louis Aliot's presence on Twitter may well have less to do with his being Marine Le Pen's partner, than with his own political role as Vice-President of the Front National. He airs his own political opinions through this account, retweets Mme Le Pen, but does not indulge in any references to the domestic sphere.

The two favourites for the position of "Première Dame" are under much more intense media pressure, though once again their strategies also differ. Valérie Trierweiler set up her own Twitter account one month before the socialist primaries, in September 2011. As a political journalist for the magazine Paris Match and the television channel Direct 8, Trierweiler had become involved sentimentally with François Hollande for several years, before he and Ségolène Royale officially ended their relationship. Trierweiler came to the front of the media stage during the election campaign itself. Her professional identity dominates, to a certain extent, her use of Twitter during the campaign, even though she also makes several references to her partner in her tweets ${ }^{8}$. She also tends to use Twitter defensively to react to or ironise about criticism she has received during the campaign.

Carla Bruni-Sarkozy had had a very publicized relationship with Nicolas Sarkozy shortly after he entered office, before the couple married far from the cameras in February 2008, inside the Élysée palace. In the run-up to the election, Sarkozy appears to have changed tack and seek to shift media attention away from the private sphere. Although their relationship continued to fuel the gossip press in France and elsewhere, Bruni-Sarkozy was very careful not to communicate outside the Élysée's official channels (including her own official website). She had no official Twitter account, and the only tweet she sent during the election period was from her husband's official Twitter account: 
“J'emprunte momentanément le compte de mon mari pour vous saluer, chers followers. Merci pour votre soutien! Carla",

Sarah Brown, wife of the incumbent Prime Minister, could not be in a more different situation to her French counterpart. A PR professional, Sarah Brown had been dubbed "high priestess of Twitter" by the Daily Mail ${ }^{10}$. She posted over 12 tweets a day on average from her SarahBrown $10^{11}$ account which had over a million followers during the period studied, i.e. over 20 times more than any of the official UK political party accounts. In the face of such a powerful presence, it is possibly not surprising that neither of the other partners had a Twitter account at this time. Miriam González Durántez, of Spanish nationality, clearly sought to position herself apart from her two rivals, explaining that she couldn't put her career on hold to accompany her husband during the campaign. ${ }^{12}$ She was much less present in the media and also less likely to become "First Lady", given the configuration of the British political landscape. Indeed, Sam Cameron was generally presented in the media and elsewhere as Sarah Brown's main rival, and her absence from Twitter appears to be a strategic choice in relation with her husband's global communication strategy. Indeed, not only did both Sam and David Cameron use the Webcameron video blog to talk directly to voters, stage their intimacy and show the "wings" of the campaign (Brachotte \& Frame, 2011), the choice to boycott Twitter was one which Cameron had to some degree inflicted upon himself in July 2009. During an interview with Christian O'Connell on Absolute Radio, he joked that "too many twits might make a twat.". ${ }^{13}$

In the US, in 2012, the Republican candidates' wives were all present at their husbands' sides in accordance with presidential tradition. However, Carol Paul and Karen Santorum, both absent from Twitter, were also the least publicly-visible partners. Callista Gingrich had been using Twitter since April 2009, and tweeted regularly in relation with her own and her husband's political activities during the period studied, though only around half as frequently once her husband had withdrawn from the race for nomination. Her number of followers in comparison with her rivals is possibly also a reflection of a proportionally low level of public interest during the primaries, since the number of followers of the other accounts rose more sharply in the later months of the campaign. In contrast, Ann Romney's Twitter account was only set up on 12th April 2012, well into the campaign itself, after she had been accused by Democrat strategist Hilary Rosen, of having "never worked a day in her life". ${ }^{14}$ The ensuing debate about "stay-at-home Mums" attracted many supporters to the newly-created Facebook and Twitter accounts set up by the Romney campaign team, including the Facebook page "Mums with Mitt". Despite only 13 messages being posted in the first 19 days of its existence, Ann Romney's Twitter account had attracted around five times as many followers as that of Cally Gingrich in that time. Its popularity continued to grow during the final six months of the 
campaign. Michele Obama's Twitter account was also only set up on $12^{\text {th }}$ January 2012, though it had attracted 750,000 followers in the first three months, and well over 2 million on Election Day. The account was explicitly run by the Obama campaign staff, though just over $14 \%$ of tweets sent during the period were signed personally by Michelle Obama.

\section{$\underline{\text { Political Tweets }}$}

It is possibly an unsurprising result that the vast majority of tweets sent from these accounts can be interpreted as having a more or less explicit political purpose or message, given the identities of the account holders. However, it is interesting to note that there appear to be different ways and degrees of being political. On one extreme, Louis Aliot and Sarah Brown both use their accounts to overtly promote their (partners”) parties: “@halenmo Labour is the party that does support all kinds of families, and believes in fairness. here is the link http://www.labour.org.uk". ${ }^{15}$ This is true also of many messages posted by the campaign team to Michele Obama's account, which overtly support Obama and the Democrat position. In signed messages, where this is the case, a more personal note can often be detected: "I am so proud of how Barack has represented us on the world stage for the past four years. Tonight he shined on the debate stage, too. - mo". ${ }^{16}$

This personal, admirational tone is also used to varying degrees by Sarah Brown, Ann Romney and Cally Gingrich, alongside more routine messages recounting various stopovers on the campaign trail:

"Had a wonderful time at \#CPAC yesterday with@newtgingrich. Read more about our day here: http://www.newt.org/callistas-canvas/callista-gingrich-cpac-2012" ${ }^{17}$ Gingrich uses this style particularly often, and it is not uncommon to find variations on the theme: "looking forward to travelling to X with my husband", followed several hours later by "had a wonderful time in X with my husband". Although all of the individuals followed tend to retweet messages from their partners, in the case of Valérie Trierweiler, possibly because of her professional identity and because she is not actually married to François Hollande, references to her companion in her own tweets to remain more veiled, often employing a collusive tone: "je vous donne rendez/vous à 19 heures sur radio hollande pour 20 minutes d'entretiens avec Pierre Lescure. \#FH2012"18 or: "Le changement - de chaîne - c'est maintenant! On se branche sur \#Direct8, pour la dernière d'itinéraires". ${ }^{19}$

However, tweets expressing political affiliation are not the only or even the most common types of tweet to be found. In general terms, the majority of tweets are about other subjects, even though these can also very often be seen to contribute to creating a certain (political) image of the partners.

Tweeting for the Female Electorate 
One of the common points to all of the female partners in the study is the role of ambassador they seem to play on "women's issues", possibly in an attempt to gain support for a partner who is less credible or legitimate on such issues. Ann Romney's first tweet: “I made a choice to stay home and raise five boys. Believe me, it was hard work" ${ }^{20}$ is an understandable reaction in the context which led to her account being set up (supra). Interestingly, 13 of her 23 first tweets, sent up until the end of May, refer directly to her role of mother or grandmother. Subsequent references to motherhood are less frequent, as Romney seems to adopt the technique of other female partners, widening her scope to women's issues in general. Alongside Romney, Michelle Obama and Sarah Brown can also be seen to comment on family issues. Independently of tweets about their own families (infra), Obama also reacts to the scandal provoked by Hilary Rosen's criticisms of Ann Romney: "Every mother works hard, and every woman deserves to be respected. -mo"21 and Brown chooses to mention a visit to a family-oriented community centre: "visited Atherton Sure Start Centre - so many activities for babies, children, mums \& dads, and a youth club - just a joy to be there". ${ }^{22}$ As well as being on the traditional socialist agenda, the interest and sympathy for families expressed by Sarah Brown may be aimed to compensate her husband's less easy and convincing manner on such questions.

Other tweets are more overtly committed to defending or celebrating women's rights, for example from Michelle Obama: “Generations of Americans marched and organized for women's rights. This Women's History Month, let's honor them with our service. - mo". ${ }^{23}$ Similar kinds of messages are sent by Sarah Brown, on political activism for the female vote: "Emmeline Pankhurst trending on Twitter. Let's remember the sacrifices the suffragettes made so we could exercise our right to vote. "24 or celebrating the female condition: "http://twitpic.com/levx4e - attending the Celebrating Women: Past, Present and Future, conference at Neasden Temple today". ${ }^{25}$ Cally Gingrich's tweets are generally less calls to defend women's or mothers' rights, but generally underline the fact that she is representing her husband at meetings of women's associations: "Great crowd at the Republican Women's Luncheon today at Food City in Kingsport, TN! http://instagram/p/HzViV1IJ4t ${ }^{\prime 2} .{ }^{26}$ She does however launch a call to join a women's association supporting her husband: "Join our Women with Newt coalition today and help us rebuild the America that we love. $\quad$ http://www.newt.org/coalitions/women/ \#withnewt". ${ }^{27}$ Finally, Valérie Trierweiler refers explicitly to women only once in a tweet sent on Women's Day: “\#forumElle. En tant que femme: heureuse et convaincue de l'engagement de@fhollande sur les questions des femmes. Notamment sur les violences". ${ }^{28}$ She does lend her support to humanitarian and other causes, but these are not associated exclusively with women.

Another popular type of message linked to the female condition concerns women's health, including 
breast cancer and childbirth. Ann Romney tweets: "It was inspiring to walk alongside so many wonderful women united to beat breast cancer. \#prettyinpink pic.twitter.com/3UiaYeQd". ${ }^{29}$ Michelle Obama underlines the impact of her husband's health reforms for women: "Thanks to Obamacare, insurance companies will no longer be able to charge women more than men for the same plan. http://OFA.BO/owm4Uy"30 or "Obamacare has expanded access to breast cancer screenings, helping patients and survivors get the care they need.pic.twitter.com/tQTdOT27". ${ }^{11}$ Tweets of this kind are slightly rarer from Sarah Brown, and often include global rather than just women's health issues, but she does send a series of tweets on the theme of maternal mortality during the month observed: "Serra Sippel of @genderhealth Blogs on Maternal Mortality Decrease. She says good news, but not "Mission Accomplished" http://bit.ly/8ZCdPa",32 and "Today is National Safe Motherhood Day in India - a big boost to the maternal mortality campaign and @WRAGLOBAL".33 Ann Romney also refers to her own past health problems and the support given to her by her partner at that time: "Routine check-ups are the key to early detection. I had my check-up yesterday, and am celebrating three years of being cancer-free". ${ }^{34}$ or "Today is World MS Day. Mitt's support when I was diagnosed got me through the most trying time of my life http://mi.tt/L3g5vD". ${ }^{35}$

\section{Tweeting in the private sphere}

Such references to personal health issues can be considered to belong to the private sphere, exploited here in a bid for compassion or sympathy, and to show Romney as a strong, caring fatherfigure. Although relatively unsurprising in a UK / US context, ${ }^{36}$ it would be much harder to imagine such tweets in French political communication, in the same way that the tweet relayed by Cally Gingrich from her husband's account, concerning a rival's sick child would doubtless be considered by a French audience as a shocking intrusion into the private sphere: “@CallyGingrich and I have @ RickSantorum and family in our prayers since their daughter bella is back in the hospital". ${ }^{37}$ Indeed, there are no references to the private sphere in Aliot's or Trierweiler's tweets, except when the latter calls for her journalist colleagues to respect this: "Quel choc de se découvrir à la Une de son propre journal. Colère de découvrir l'utilisation de photos sans mon accord ni même être prévenue". ${ }^{38}$

Elements from the private sphere are thus much more widely evoked in the English-speaking tweets, possibly in response to higher media demand for such information. The strategy adopted appears to combine a desire to portray the partner as exemplary in his private life, through the roles of husband and father, while casting him in a domestic sphere to which followers can relate.

This strategy implies that the partner herself be cast in the role of "traditional" spouse, which can appear slightly inconsistent with the calls for equal rights referred to previously (supra). Thus Sarah 
Brown, the successful career woman and co-founder of her own PR firm, cultivates a persona on Twitter who exchanges cooking recipes with her followers: "RT@judithoreilly I tried out your recipes for lamb and crumble last night. They get my vote. http://bit.ly/9Hz9Cn [SO PLEASED!]". ${ }^{39}$ She also mentions in passing how much she loves supermarkets (in general of course - no particular brand preferences!): “@msjodavies I love pretty much every supermarket - I know not everyone likes a supermarket shop but I really really do". ${ }^{40}$ The strategy seems to consist in showing the Labour leader's wife as an 'ordinary' person, who is happy to share with her million followers her complex about not having straight toes, or the fact that she stained her skirt by sitting on a pen: "2nd mishap of the campaign for me after \#feettweet: discover my favourite skirt has huge inkblot on the back from sitting on a pen \#bottblot". ${ }^{41}$ Brown is careful only to give such intimate details about herself, always showing her husband in a positive light and in a position as strong leader. If he had been the one to stain himself, she would most certainly not have tweeted about it. She plays the role of his 'ordinary', accessible 'other half', encouraging followers to identify with him through her.

In the US corpus, certain tweets also highlight the 'everyday behaviour' of the couples in the presidential contest. This is absent from Cally Gingrich's tweets, but true to a certain extent of Michelle Obama and Ann Romney, though generally less towards the end of the campaign. Obama uses a confidential tone to her followers: "It was great to sit down for dinner with a few new friends last night. My date had a great time, too. - mo", ${ }^{42}$ or writes public messages for her husband: "I wonder howAl Green ended up on our playlist, @BarackObama!-mo". ${ }^{43}$

Despite the fact that there are fewer self-references, family appears to be foregrounded to a greater extent in Obama and Romney's tweets than in those of Brown. They both celebrate various family birthdays and anniversaries. From Obama: "Happy Fourth! What makes this day even more special is that it's the day our first child was born. Happy birthday, Malia! We love you. -mo"; "4 "Happy 20th anniversary, Barack. Thank you for being an incredible partner, friend, and father every day. I love you! -mo"; ${ }^{45}$ including the dog's: "It's a big 4th birthday for Bo! He's getting some extra treats today. -mo". ${ }^{46}$ From Romney: "Thank You Matt! Love You RT @Matt_Romney Happy Birthday @,AnnDRomney! Wish we could celebrate with you today mom, but see you soon!". ${ }^{47}$ Mother's Day and Grandmother's Day are also celebrated: “RT@joshromney@AnnDRomney,where r u? I need to know where to send annual \#MothersDay coupon book with promises to clean my room, do dishes"; 48 "I want to wish a very happy Mother's Day to all of the moms out there, especially mine. She's my rock every single day. Love you, mom. -mo". ${ }^{49}$ Ann Romney also talks about her grandchildren and even posts photos of them to her Twitter account: "Grandchildren 17 and 18 are here-congratulations@TRomney and Jen! We can't wait to meet David and William".50 


\section{Conclusion}

The conclusions drawn from this study can be tentative at best. Not only was the approach a limited qualitative one relying on interpretation of a very small number of accounts, but the exclusive focus on Twitter elides everything else which was being said through other media channels and gives a very partial picture of the partners' communication during the election campaigns, in which Twitter remained a fairly minor communication tool. While that does not invalidate its choice as an object of study, further cross-media research taking into account notably the communication strategies of those partners who chose to communicate to different channels, could provide some interesting points of comparison. Despite these limits, the study does appear to bring to light certain practices which could be interesting to study in more detail during subsequent campaigns.

Whether they express themselves through Twitter or other channels, partners of potential national political leaders face considerable pressure from the media and often from their parties to play a role in their partners' campaigns. If they accept to sacrifice their own voice and views to this political role, their unique position gives them a forum from which they can contribute singularly to their partner's image, as Christiane Restier-Melleray (2002: 124) points out. This was most evident in the three accounts with the largest numbers of followers: those of Sarah Brown, Michelle Obama and Ann Romney. These three women all give a positive image of their partners, underlining their moral integrity and family values and referring explicitly to their husbands' strength and to their mutual/family love and support. More than her American counterparts, Sarah Brown also tweets banal details of the everyday life she shares with the Prime Minister, playing the role the traditional housewife and encouraging her followers to identify with her. This strategy, if taken at face value by her audience, appears to avoid some of the risks associated with politicians who try themselves to give the image of being "normal" people. By making herself seem "ordinary", Sarah Brown helps others identify with her husband, without revealing potentially belittling details about him and without him needing to risk media and public scorn through artificial attempts to promote his own "normality".

Could the role of the partner described here thus be a way for political communicators to exploit the trend for personification of politics (Stanyer, 2013) while allowing the leader him/herself to retain a degree of distance compatible with the image of a charismatic leader? To what extent does the admiration expressed by the partner offset the "normality" also portrayed and which might detract from the leader's perceived charisma? To answer such questions, more extensive research would be required. Indeed, the fact that the "normality" described here is, in many cases, quite clearly staged may paradoxically contribute to the idea that in reality, the leader is not normal, since they are 
obliged to adopt artifices to prove that they are!

More generally, by tweeting about women's issues, and notably by confirming their partners' support for them, the four English and American women seem to be aiming at a wider female electorate to which their husbands are maybe less able to appeal. This is a key difference with the French corpus, where even Valérie Trierweiler seems to speak as much from her own point of view as from that of her partner. Although the corpus is evidently too small and idiosyncratic to be a source of any meaningful national comparisons, the absence of the private sphere from the French tweets appears coherent with the idea that the distinction between public and private in France is still widely accepted by public opinion, despite recent signs of evolution (Stanyer, 2013: 1-2;). Independently of the gossip press's appetite for speculation about politicians' private lives, coverage in France still remains limited for legal, but also cultural reasons. Although Nicolas Sarkozy appeared to want to venture into this area during the first part of his presidential term, famously visiting Disneyland with Carla Bruni, the criticism he received, or that directed at Hervé Morin when the latter shot a video in his own kitchen, suggests that French society is not yet ready to sacrifice this founding principal of the notion of la citoyenneté. Can this be interpreted as a sign that the French reject the idea of "normality" in their leaders, incompatible with the hierarchical distance between politicians and their electorate? If Sarkozy seems to correspond to the ideal of "charismatic leader", he was beaten by a rival who marketed himself as "un president normal", yet François Hollande's lack of perceived charisma is arguably one of the keys to his unpopularity two years on. Daniel-Louis Seiler (2002: 163) has noted that countries which seem to disprove of media coverage of politicians' private lives are generally more tolerant towards immoral behaviour on their part. He suggests that the difference lies in national cultural and religious heritage. Whereas Englishlanguage media coverage of politician's private lives might be criticised by the French for a lack of respect for the individual, in many English-speaking and Northern European traditionally protestant societies, writes Seiler, voters see this as a necessary form of transparency. For them, politicians are first and foremost individuals, whose moral behaviour in the public sphere will likely reflect that of the private sphere. As elected representatives of the people, if they are to serve and represent the people well, politicians must be beyond reproach, and voters have a "right to know". From a French and, argues Seiler, more globally a Southern European point of view, marked by a Roman Catholic heritage, politicians are seen as individuals who have a right to live their private lives as they choose, as long as it does not interfere with the way they exercise in the public sphere. This distinction between public and private runs deep into the social pact underlying the French Fifth Republic, justifying the division between the Church and the State, among other things. ${ }^{51}$

Indeed, it should not be neglected that the question of the relationship between leaders and 
followers, addressed by all the contributions to this book, is inextricably linked not only to specific political circumstances and contexts, but also to the cultural heritage of the party and the society in question. As this chapter has pointed out, use of Twitter by the partners of political leaders was linked to a variety of factors, including their own professional identity and activity, their marital status, the relative likelihood of their partners being elected, the individual image of the latter and the specific communication strategies they adopted during their campaigns. However, the party identity, the wider media context and the cultural norms, practices and representations surrounding the distinction between private and public all also contributed to the way each partner sought to help their candidate construct their particular image of leader.

\section{Works Cited}

Alexandre-Collier, A. (2010) Les habits neufs de David Cameron. (Paris: Presses de Sciences Po. $\mathrm{p} / \mathrm{cops})$.

Brachotte, G. \& Frame A. (2011) “Appropriation et usages des TIC chez des "leaders" politiques en France et en Grande-Bretagne: pratiques et discours". In F. Liénard \& S. Zlitni (eds.), La communication électronique, enjeux de langues, 65-76. Limoges: Lambert-Lucas.

Corner, J. (2003) "Mediated Persona and Political Culture". In J. Corner \& D. Pels (eds.) Media and the Restyling of Politics: Consumerism, Celebrity and Cynicism, 67-84. (London: Sage).

Craig, G. (2014) ““A walking, talking news factory’: David Cameron, performance politics, and everyday life". Conference paper presented at MeCCSA 2014 "Media and the Margins", University of Bournemouth, 8-10 Jan. 2014.

Dang-Anh, M. Einspänner, J. \& Thimm C. (2012) "Mediatisierung und Medialität in Social Media: Das Diskurssystem „Twitter““. Sprache und Kommunikation im technischen Zeitalter: Wieviel Internet (v) erträgt unsere Gesellschaft? 2: 68.

Fox, R. L. \& Ramos, J. (eds.) (2012) iPolitics: citizens, elections, and governing in the new media era. (Cambridge University Press).

Frame, A. (2012) “Too many Twits? Réseaux sociaux et mise en scène de l'intimité par les 
candidats aux élections législatives britanniques en 2010”. In S. Crinquand \& P. Bravo (eds.), L'intime à ses frontières. 77-91. (Cortil-Wodon: E.M.E).

Frame, A. \& Brachotte, G. (2013) "Les campagnes des compagnes: Mise en scène de la vie publique et privée”. In F. Liénard \& S. Zlitni (eds.) La communication électronique en questions, 387-402, (Bern: Peter Lang AG).

Goffman, E. (1959) The Presentation of Self in Everyday Life. (New York: Doubleday).

Lilleker, D. \& Jackson, D. (2013) Political Campaigning, Elections and the Internet: Comparing the US, UK, France and Germany. (London: Routledge).

Restier-Melleray, C. (2002) "Les formes d'interventions journalistiques dans l'évocation de l'intimité". In P. Baudry, C. Sorbets, \& A. Vitalis (eds.) La vie privée à l'heure des médias, 123-138. (Presses Universitaires de Bordeaux).

Seiler, D.-L. (2002) 'L'usage politique de la vie privée des hommes politiques en démocratie”. In P. Baudry, C. Sorbets, \& A. Vitalis (eds.) La vie privée à l'heure des médias, 149-165. (Presses Universitaires de Bordeaux).

Stanyer, J. (2013) Intimate Politics: Publicity, Privacy and the Personal Lives of Politicians in Media Saturated Democracies. (Cambridge, UK: Polity Press).

Thimm, C. (2011) “The Visuals of Online Politics: Barack Obama’s Web Campaign”. In: V. Depkat, \& M. Zwingenberg (eds.) Visual Cultures - Transatlantic Perspectives, 185-203. (Publications of the Bavarian American Academy, ${ }^{\circ}{ }^{12}$ ).

Vergara, C. (2012) Valérie, Carla, Cécilia, Bernadette et les autres, en campagne. (Paris : Tallandier).

Weber, M. (1947 [1922]) The Theory of Social and Economic Organization. Translated by A. M. Henderson and Talcott Parsons. (New York: Oxford University Press). 
James Stanyer defines intimization as: "a revelatory process which involves the publicizing of information and imagery from what we might ordinarily understand as a politician's personal life - broadly defined" (2013, 14). As the author points out, intimization can correspond to both "flows of non-scandalous personal information and imagery consensually co-disclosed in the media and scandalous information" and "imagery gathered and publicized in the public realm without a politician's consent" $(2013,17)$.

2 John Corner (2003, 73) distinguishes (i) public/popular, (ii) political and (iii) private spheres, but Stanyer (2013, 13) prefers "personal" to private, suggesting that, once disclosed, the information in question is no longer strictly "private". Notwithstanding this objection, the terminology adopted here is that of Corner, since it is the sphere which can be considered "private", rather than the information.

3 Video posted on 10.06.2010. Accessed on 15.01.2014. Available at: http://www.conservatives.com/Video/Webcameron.aspx?id=220cb871-b6cf-4f89-87b6-f30d99f87d8c.

${ }^{4}$ For the sake of clarity and simplicity, the term "partners" will be used throughout this chapter, to cover the wives and other female and male partners included in the study.

${ }^{5}$ Figures in brackets are valid for 2nd May 2010, when Newt Gingrich officially withdrew from the race for Republican nomination.

${ }^{6}$ Figures in brackets correspond to tweets signed "mo", indicating, according to the account profile, that they were sent by Michelle Obama herself, rather than by Obama campaign team staff.

$7 \quad$ Sources: <http://blog.sysomos.com/2010/01/14/exploring-the-use-of-twitter-around-the-world/>, <http://wallblog.co.uk/2012/04/19/how-big-is-twitter-in-2012-infographic/> for the UK and the US ; $<\mathrm{http}$ ://www.lemondeinformatique.fr/actualites/lire-la-france-compte-5-2-millions-de-comptes-twitter-47622.html $>$ for France. Pages accessed on 15.01.2012.

8 Trierweiller's highly controversial Tweet, shortly after becoming First Lady, which went against both Hollande and the Socialist Party line to support a dissident socialist candidate running against Ségolène Royale during the June 2012 parliamentary elections, led her to later become much more cautious in her use of the medium, while sparking a national debate about the role and freedom of speech of an (unmarried) First Lady who happened to be a political journalist.

9 “I am briefly borrowing my husband's account to say hello, dear followers. Thank you for your support. Carla.” (Our translation).

$10<$ http://www.dailymail.co.uk/debate/article-1264068/JAN-MOIR-War-wives-How-did-Sarah-Brown-SamCamcompare-fashion-stakes.html>. (Page accessed on 15.01.14).

11 When her husband left office, the account's name was changed to "SarahBrownUK". It still had over 1,180,000 followers in April 2012.

$12<$ http://www.telegraph.co.uk/news/election-2010/7558842/Election-2010-the-battle-of-the-leaders-wives.html $>$ (Page accessed on 15.01.14).

${ }^{13}<$ http://www.youtube.com/watch?v=d3Mrfut-FSw $>$ (Page accessed on 15.01.14). After becoming Prime Minister and apologizing for this "gaffe", Cameron finally opened his official Twitter account in October 2012.

$14<$ http://usatoday30.usatoday.com/news/politics/story/2012-04-12/ann-romney-hilary-rosen-work/54235706/1> (Page accessed on 15.01.14).

15 Tweeted on 02.03 .10 .

16 Tweeted on 23.10.12.

17 Tweeted on 11.02.12.

18 "Meet me at 7pm on hollande radio for 20 minutes of interviews with Pierre Lescure.\#FH2012". (Our translation). Tweeted on 01.05.12.

19 "Time to change - channels! Turn over to Direct 8 for the last episode of Itinéraires". (Our translation). Tweeted on 06.04.12.

${ }^{20}$ Tweeted on 11.04.12.

21 Tweeted on 12.04.12.

22 Tweeted on 15.04.10.

${ }^{23}$ Tweeted on 08.03.12.

24 Tweeted on 06.05.10.

${ }^{25}$ Tweeted on 11.04.10.

${ }^{26}$ Tweeted on 05.03 .12

${ }^{27}$ Tweeted on 11.03 .12 .

${ }^{28}$ Tweeted on 08.03.12. “\#forumElle. As a woman: happy and convinced about @ fhollande’s commitment to women’s issues. Especially on violence." (Our translation).

${ }^{29}$ Tweeted on 20.10.12.

${ }^{30}$ Tweeted on 19.10.12. 
${ }^{31}$ Tweeted on 13.10.12.

32 Tweeted on 20.04.10.

${ }^{33}$ Tweeted on 11.04.10.

34 Tweeted on 21.08.12.

35 Tweeted on 30.05.12.

${ }^{36}$ In the British context, both Cameron and Brown have lost children and this information has been relayed by the media.

37 Tweeted on 06.04.10.

38 "What a shock to discover oneself on the front of one's own magazine. Angry to discover that the photos were used without my permission or prior knowledge" (Our translation). Tweeted on 08.03.12.

${ }^{39}$ Tweeted on 20.04.10.

${ }^{40}$ Tweeted on 17.04.10.

${ }^{41}$ Tweeted on 19.04.10.

${ }^{42}$ Tweeted on 09.03.12.

${ }^{43}$ Tweeted on 12.02 .12

${ }^{44}$ Tweeted on 04.07.12.

${ }^{45}$ Tweeted on 03.10.12.

46 Tweeted on 09.10.12.

${ }^{47}$ Tweeted on 17.04.12.

${ }^{48}$ Tweeted on 11.05.12.

${ }^{49}$ Tweeted on 13.05.12.

${ }^{50}$ Tweeted on 04.05.12.

51 The 2011 sexual scandal involving Dominique Strauss-Kahn came to light in the US, despite the fact that his behaviour had allegedly previously been public knowledge in political circles in France. Revelations about François Hollande's "affair" with a Parisian actress in January 2014 were similarly brushed aside as "private matters" by the President at a subsequent press conference. 